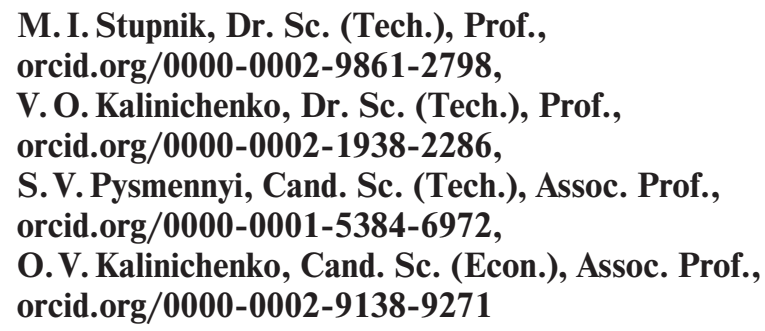

\title{
DETERMINING THE QUALITATIVE COMPOSITION OF THE EQUIVALENT MATERIAL FOR SIMULATION OF KRYVYI RIH IRON ORE BASIN ROCKS
}

\begin{abstract}
Purpose. To develop a model of composition of Kryvyi Rih iron ore basin through laboratory investigation of equivalent material.

Methodology. Methods of mathematic simulation and experimental research are used.

Findings. Conditions of model and prototype similarity are determined; dependencies of physical and mechanical properties of equivalent material rocks on percentage ratio of its components are developed. As a result of the research, it is established that while simulating rocks of Kryvyi Rih iron ore basin in laboratory conditions it is reasonable to use the equivalent material based on a sand-paraffin mixture containing granite chips, fine cast iron, quartz sand, mica and paraffin. The quantitative composition of the mixture is found to be similar to rocks of Kryvyi Rih iron ore basin in the following proportions: cast iron and granite chips $-34 \%$, quartz sand, mica and paraffin $-66 \%$. Approximation of the dependencies results in empirical equations of Poisson's ratio and the horizontal stress of the equivalent material which depend directly on the percentage of cast iron, granite chips and paraffin. Poisson's ratio and the horizontal stress of the equivalent material are proved to grow with the increasing percentage of paraffin in the equivalent material.
\end{abstract}

Originality. For the first time, there have been determined empirical dependencies of Poisson's ratio and ultimate strength of the material on the percentage of paraffin and cast iron. Poisson's ratio and the coefficient of the horizontal stress of the sand-paraffin based equivalent material depend on proportions of paraffin and cast iron and are described by the power function.

Practical value. The results of the laboratory investigations enable creation of a sufficiently precise rock mass model to investigate processes in rocks at underground development of iron ore deposits over time.

Keywords: Poisson's ratio, equivalent material, similarity, model, scale, sand-paraffin mixture, cast iron, mica

Introduction. Kryvyi Rih iron ore basin is situated in the area of the Inhulets River and its left tributaries the Saksahan and the Zhovta. The basin is made of crystalline rocks of the ferruginous formation occurring as a narrow band of metamorphic ores in granites. It runs south and north for $100 \mathrm{~km}$ and is part of Kryvyi RihKremenchuk deposit. The rock complex of part of Kryvyi Rih-Kremenchuk deposit series is folded meridionally and forms a large folded structure consisting of the Novokryvorizka, Skelevatska, Saksahanska, Hdantsevska and Hleievatska suites [1, 2].

The Novokryvorizka suite $\left(P R_{1} n k\right)$ consists of amphibolite with interlayered schist. The horizontal thickness of the series varies from $210 \mathrm{~m}$ in the north to complete pinchout in the south.

The Skelevatska suite ( $P R_{1} s k$ ) consists of quartzite, arcose, phyllite and talc schist. The horizontal thickness of the series varies from $7 \mathrm{~m}$ to $150 \mathrm{~m}$.

The Saksahanska suite $\left(P R_{1} s x\right)$ overlies the Skelevatska suite rocks and is the main ore-bearing formation. Within the deposit it is presented by alternating

(C) Stupnik M. I., Kalinichenko V. O., Pysmennyi S. V., Kalinichenko O. V., 2018 seven schist and seven ferruginous layers. The horizontal thickness of the series is about $1300 \mathrm{~m}$. The ferruginous layers are composed of martite, gothite-hematitemartite, silicate-carbonate-magnetite, silicate-magnetite and magnetite ores with schist breaks. Schist layers are presented by quartz-sericite-chlorite and other schists with ore-free bands. The thickness of the schist layers is $20-100 \mathrm{~m}$.

The Hdantsevska and Hleievatska suites occur in the hanging wall of the Saksahanska suite and are made of quartz-biotite, quartz-coal-mica schist, metasandstone, conglomerates, graphite-quartz-mica micro-schist, dolomitic marble and metasandstone, quartzite, quartzsericite-graphite and other schists. The total thickness of the suite is about $4800 \mathrm{~m}$.

Operating enterprises of Kryvyi Rih iron ore basin apply underground methods for mining rich ores of the hanging wall of the Saksahanska series below $1135 \mathrm{~m}$. Dramatic worsening of the rock extraction degree at great depths $(1315 \mathrm{~m}$ and lower) results in increased mining costs [3, 4].

Analysis of project design documents show that the worsening of the rock extraction degree does not result in deterioration of mining and geological conditions 
only, but also in considerable values of rock pressure. Increase in the extraction degree can be achieved through changing the underground mining technology. This requires forecasting the rock behavior within and beyond a stope at the stage of designing $[5,6]$. Forecasting the rock mass behavior is possible through mathematical, computer or physical simulation in laboratory conditions.

Currently, there exist a great number of software systems capable of forecasting a rock movement zone, working and stope stress distribution at underground mining at Kryvyi Rih iron ore basin. However, these software systems do not consider the whole range of factors impacting the rock mass under real conditions of underground mining and the time factor. Building a dynamic computer model appears to be a complicated and in some cases unsolvable task [7, 8].

Thus, to forecast rock stress changes in dynamics is possible through physical simulation on equivalent materials in laboratory conditions.

Analysis of the recent research and publications. Strain-stress state values on the rock model boundaries are known to differ from those in the middle of the simulated area as in this case there exists connection with the surrounding massif. Therefore, mechanical processes on the model boundaries will slightly differ from natural ones $[9,10]$.

In laboratory simulation it is of significant importance to observe boundary conditions of the model and the natural environment. When solving volumetric tasks, the simulated and real area boundary conditions should be similar $[9,11]$.

The similarity of the system is achieved through preparing the equivalent material of a certain composition with corresponding physical and mechanical properties. The necessary qualitative composition of the equivalent material mixture provides observance of the boundary conditions and allows replicating the initial stress-strain state before underground mining operations.

Selection of a filler and adhesives for the equivalent material depends, first of all, on physical and mechanical properties of the rock massif under investigation and the observance of necessary initial parameters according to the adopted simulation scale [11]. Preparation of a good quality composition of the equivalent material is a time, material and labor consuming process $[12,13]$.

To reduce the time for selection and preparation of the adequate equivalent material, the number of laboratory tests of samples, a special technique should be developed for determining the qualitative composition of an equivalent material corresponding to physical and mechanical properties of rocks in nature considering the similarity criterion $[5,10]$.

Unsolved aspects of the problem. When determining strain characteristics of a sample, it is necessary to measure their strains in longitudinal and transverse load directions. Samples are tested under various loads to provide stable conditions on the sample-press plate interface with the initial stress $\sigma_{0}$ not exceeding $5-10 \%$ of the sample destruction load [11, 14].
At each load stage, longitudinal $(\Delta h)$ and transverse $(\Delta b)$ strains of the samples are registered and then the coefficient of relative transverse strain is determined as follows

$$
\mu=\frac{\varepsilon_{b_{i}}}{\varepsilon_{h_{i}}}=\frac{h \cdot\left(\Delta b_{i}-\Delta b_{0}\right)}{b \cdot\left(\Delta h_{i}-\Delta h_{0}\right)},
$$

where $h$ and $b$ are the initial height and width of the sample, $\mathrm{cm} ; \Delta h_{0}$ and $\Delta b_{0}$ are longitudinal and transverse strains of the sample respectively at the initial stress $\sigma_{0}$.

The elastic modulus depends on stresses in the sample and is determined according to the formula

$$
E=h \cdot\left(\sigma_{i}-\sigma_{0}\right) / \Delta h_{0 i},
$$

where $\sigma_{i}$ and $\sigma_{0}$ are stresses in the sample at the $i^{\text {th }}$ load degree, $\mathrm{kg} / \mathrm{cm}^{2} ; \Delta h_{0 i}$ is the sample strain after the stress relief to its initial stress value $\sigma_{0}$, determined by the formula

$$
\Delta h_{0 i}=h_{0 i}-h_{i},
$$

where $h_{0 i}$ is the height of the sample at the $i^{\text {th }}$ load degree; $h_{i}$ is the height of the sample after the stress relief to its initial stress value $\sigma_{0}$.

So, to select the qualitative composition of the equivalent material which corresponds to each rock type of the massif, over 150 samples should be prepared and tested. In the course of preparing a great number of samples there is a probability of error accumulation that will affect the results of investigating a process or an object [15].

Objectives of the article. To avoid error accumulation when preparing the equivalent material and reduce the number of laboratory tests of samples, it is necessary to design a technique for determining the qualitative composition of the equivalent material with physical and mechanical properties similar to those of Kryvyi Rih iron ore basin rocks considering the similarity criterion.

Presentation of the main research. To receive data on a phenomenon under investigation, an auxiliary artificial object (a model) possessing certain reliable similarity to an object under investigation at separate stages is studied. The laboratory simulation is based on choosing a similarity theory and a model scale as well as on determining boundary conditions of the object and the model under which these processes are similar.

Certain known properties of similar physical phenomena make it possible to describe mechanically similar systems. In this case, all parameters describing mechanical processes in one system can be obtained just by multiplying corresponding parameters of another system by constant conversion factors [11]. Here, parameters of dissimilar physical nature have different factors, but for parameters of the same type this factor (the similarity constant) has a single conservative value.

When simulating a rock pressure manifestation using equivalent materials, the method developed by Professor G. N. Kuznetsov is a routine one. It is applied when solving a wide range of problems of rock movement and changes of the stress-strain state in the rock massif surrounding stopes, preparatory and permanent workings. 
Correlation of physical and mechanical properties of the model made of artificial materials and corresponding properties of natural rocks considering geometrical similarity is determined according to the dynamic similarity law by the formula

$$
\frac{P_{m}}{\rho_{m} \cdot l_{m}^{2} \cdot v_{m}^{2}}=\frac{P_{n}}{\rho_{n} \cdot l_{n}^{2} \cdot v_{n}^{2}}=\text { idem }=K,
$$

where $P_{m}, P_{n}$ are forces in the model and prototype respectively; $\rho_{m}, \rho_{n}$ are density of model and natural materials respectively; $v_{m}, v_{n}$ are the movement speed of initial points in the model and prototype respectively; $K$ is the similarity criterion.

Strength and elastic parameters the model material should possess at the adopted geometrical simulation scale, the relation $l_{m} / l_{n}$ of strength characteristics (or the elastic modulus) of the natural material and $\gamma_{m}$ and $\gamma_{n}$ should satisfy the condition

$$
\left\{\begin{array}{l}
\frac{[\sigma]_{m}}{\gamma_{m} \cdot l_{m}}=\frac{[\sigma]_{n}}{\gamma_{n} \cdot l_{n}} \\
\frac{E_{m}}{\gamma_{m} \cdot l_{m}}=\frac{E_{n}}{\gamma_{n} \cdot l_{n}}
\end{array}\right\}=K,
$$

where $\gamma_{m}, \gamma_{n}$ are density of the model and natural materials respectively; $[\sigma]_{m}$ is the strength parameter of the model material; $[\sigma]_{n}$ is the strength parameter of the natural material which corresponds to that of the model; $E_{m}$ and $E_{n}$ are the elastic modulus of the model and prototype respectively.

As a rule, when simulating mechanical processes in the rock massif which occur in mining, the similarity of the following physical and mechanical characteristics of the equivalent material should be observed: compressive strength, tensile strength, bending strength, elastic modulus, adhesion, plastic and rheological characteristics. The internal friction angle and Poisson's ratio should be the same in both the model and prototype

$$
\left\{\begin{array}{l}
\mu_{m}=\mu_{n} \\
\rho_{m}=\rho_{n}
\end{array}\right.
$$

where $\mu_{m}, \mu_{n}$ are Poisson's ratio of the model and prototype respectively.

While determining the qualitative composition of the equivalent material, there were prepared over 100 laboratory samples composed of quartz sand, mica, granite chips, cast iron and paraffin with the similarity coefficient of 0.05 .

Quartz sand (70\%) of the equivalent material functions as a filler. Cast iron and granite chips (28\%) simulate volume weight of rocks. It should be noted that when the volume of cast iron is increased from 2 to $20 \%$, the volume of granite chips is reduced from 26 to $8 \%$ and the volume weight of the equivalent material increases from 2.31 to $3.39 \mathrm{~kg} / \mathrm{cm}^{3}$.

The technology of preparing the equivalent material from sand-paraffin mixture consists in the following: quartz sand is dried, sieved (sieve meshes of less than
$1 \mathrm{~mm}$ ), and heated to $130{ }^{\circ} \mathrm{C}$. Then crushed paraffin is added. The mixture is stirred for $25-30 \mathrm{~min}$ at $130 \pm 3{ }^{\circ} \mathrm{C}$.

Elastic parameters of the equivalent material are determined using the statistical method on samples of $50 \times 50 \times$ $\times 100 \mathrm{~mm}$. The sample height-length ratio is not less than $2: 1$ to create homogeneous uniaxial stress at loading.

The increasing load is applied to the prepared and processed sample until its complete destruction [15].

The sample compressive strength is characterized by the maximum load at which it is destroyed.

During the laboratory tests dependencies of the initial stress field, Poisson's ratio and compressive resistance on the equivalent material composition were built (Figs. 1-3).

As shown in Fig. 1, with the increase in cast iron percentage from 2 to $20 \%$ the initial stress field in the massif grows from 900 to $1600 \mathrm{~kg} / \mathrm{cm}^{2}$ with the paraffin content of $2 \%$. When paraffin grows from 1.6 to $2.4 \%$ with $20 \%$ of cast iron in the mixture, the initial stress field grows from 600 to $2400 \mathrm{~kg} / \mathrm{cm}^{2}$. So, the cast iron percentage in the equivalent material enables creating the required initial stress field.

It should be noted that to observe the second similarity theorem, Poisson's ratio of the model and nature should have the same value.

As a result of the laboratory tests, Fig. 2 shows the determined dependencies of the cast iron percentage in the equivalent material on Poisson's ratio.

These dependencies show that the required Poisson's ratio in the equivalent material can be obtained through changing percentage of cast iron and granite chips. For the model to describe the natural material with Poisson's ratio of 0.35 , the cast iron content in the equivalent material should equal 5 or $14 \%$, the granite chips content being 23 or $14 \%$ with the paraffin content of 2.4 or $2.2 \%$

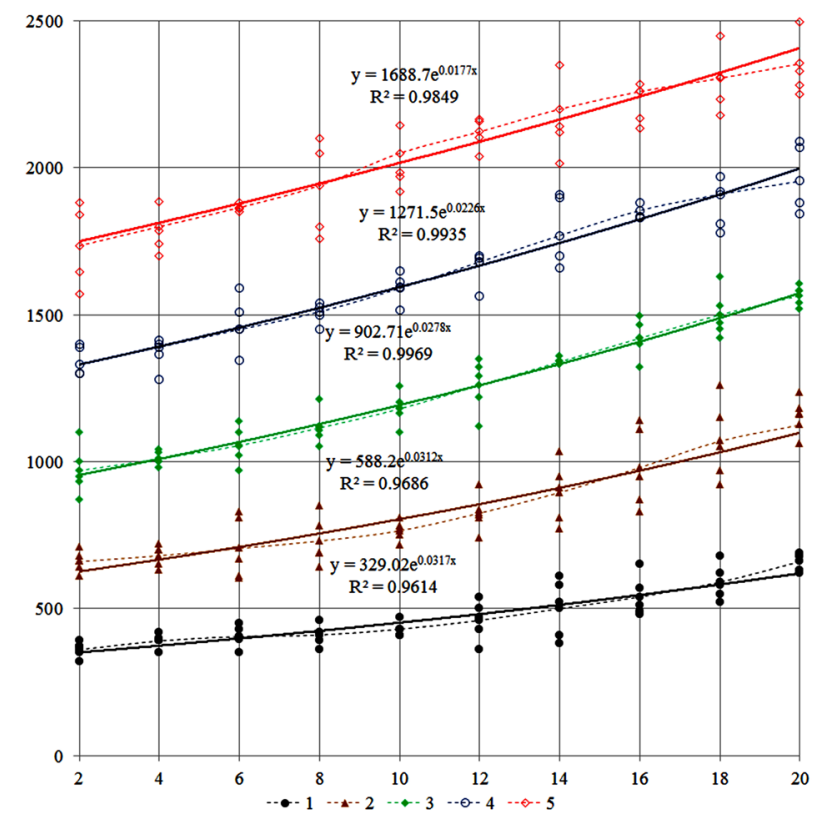

Fig. 1. Dependency of the initial stress field in the massif on the cast iron percentage in the equivalent material: $1-5$ the paraffin percentage of 1.6, 1.8, 2.0, 2.2 and $2.4 \%$ respectively 


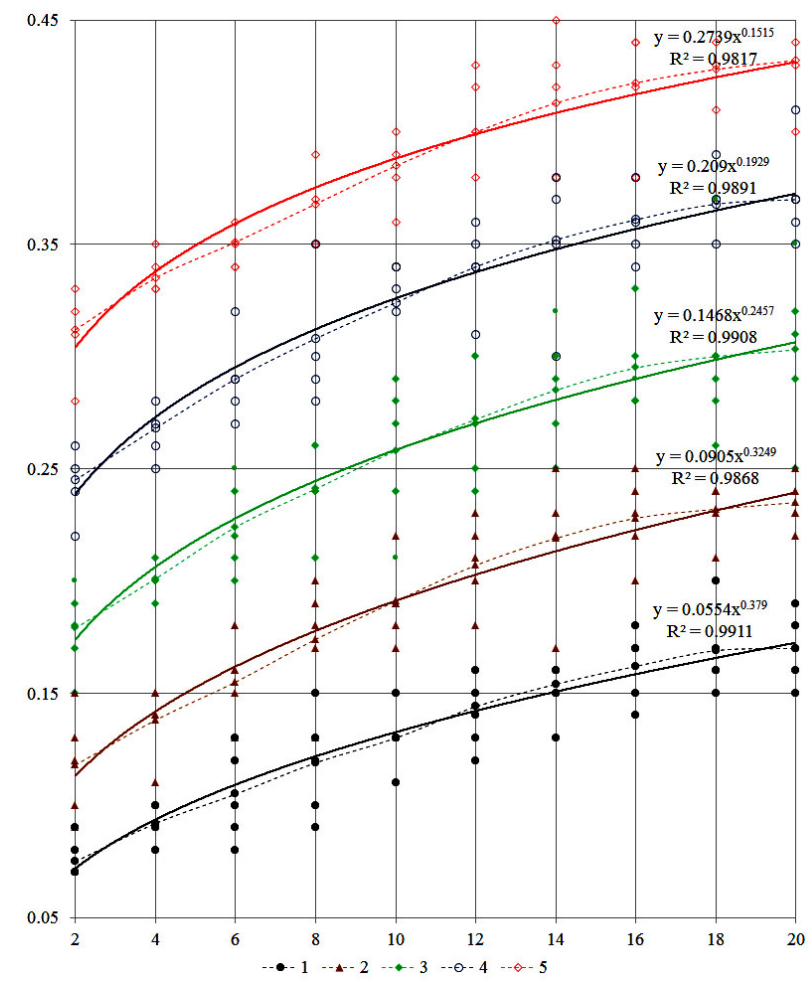

Fig. 2. Dependency of the cast iron percentage in the equivalent material on Poisson's ratio:

$1-5$ the paraffin percentage of 1.6, 1.8, 2.0, 2.2 and $2.4 \%$ respectively

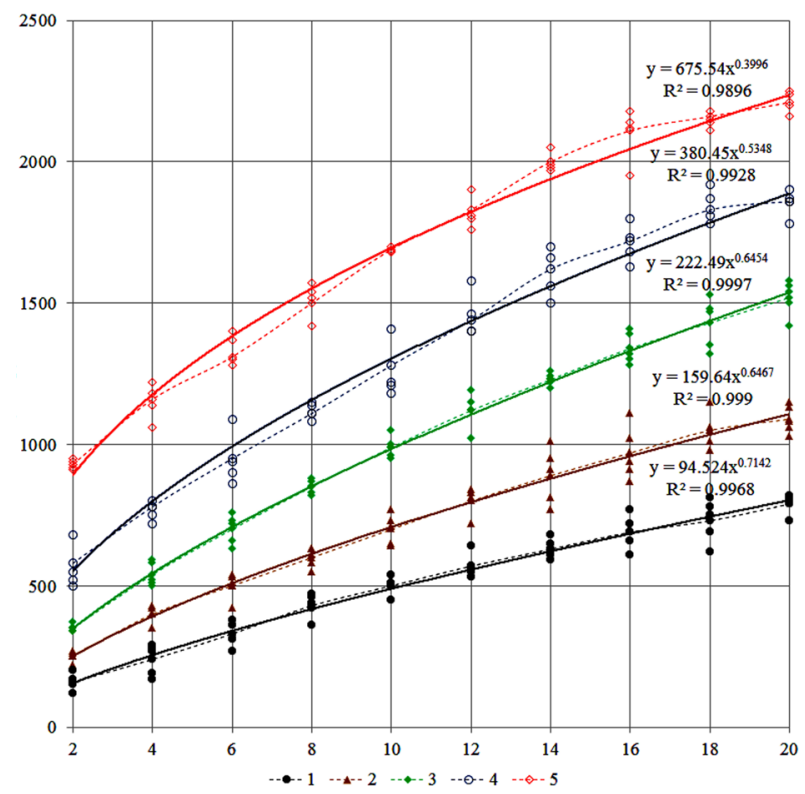

Fig. 3. Dependency of the sample ultimate strength on the cast iron percentage in the equivalent material:

$1-5$ the paraffin percentage of 1.6, 1.8, 2.0, 2.2 and $2.4 \%$ respectively

respectively of the total volume of the material.

The dependencies resulted from the laboratory tests (Fig. 2) are approximated by power functions and described by empirical equations with the validity factor of 0.9 .
While simulating mechanical processes in the rock massif, the similarity of the equivalent material compressive strength should be observed. The laboratory tests resulted in the dependencies of the equivalent material compressive strength changes on the cast iron percentage. The obtained dependencies are equal to corresponding dependencies of the natural material.

Fig. 3 shows the dependencies describing the equivalent material ultimate strength changes on the percentage of the cast iron content and granite chips. With the increase in cast iron in the equivalent material from 2 to $20 \%$ and paraffin from 1.6 to $2.4 \%$, the ultimate strength grows from 150 to $2500 \mathrm{~kg} / \mathrm{cm}^{2}$.

The given dependencies (Figs. 1-3) show that the initial stress field, ultimate strength and Poisson's ratio of the samples are influenced not only by the cast iron and granite chips percentage, but also by the paraffin content in the equivalent material. The investigation resulted in the fact that growth in the paraffin percentage in the equivalent material from 1.6 to $2.4 \%$ increases the sample ultimate strength and Poisson's ratio.

Table 1 presents values of the mean-square deviation and the uniformity factor of the massif.

According to laboratory data processing techniques developed by G.M.Malakhov, V.V. Kulikov and M.V.Kirpichov, a mean-square deviation should not exceed $15 \%$ of the average data, the uniformity factor of the massif should not exceed $25 \%$. Based on the laboratory test results, the mean-square deviation changes within $2.2-13.5 \%$, the maximum uniformity factor value makes $18.2 \%$ (Table 1 ).

The mean-square deviation of the laboratory test data changes from 3 to $10 \%$ depending on the composition of the sand-paraffin mixture at the maximum uniformity of the massif of $7.96 \%$.

The coefficient of the horizontal stress on the boundaries of the model is determined as follows

$$
\varepsilon=\frac{K \cdot \mu}{1-\mu} .
$$

The width of the horizontal stress change zone on the boundaries of a working depends on the simulation scale and the model similarity factor. According to the investigation conducted, the horizontal stress stabilizes and remains unchanged. With the percentage of paraffin in the equivalent material increasing from 1.5 to $2.4 \%$, the width of the zone where the horizontal stress stabilizes decreases from 12 to $5 \mathrm{~cm}$.

When simulating stability of structural elements of room systems in laboratory conditions, the time factor should be considered in addition to mechanical and geometrical criteria as the rock massif is destroyed over time. It is concluded that the rock massif is destroyed due to micro-fractures that are formed long before uniformity loss becomes visible. The duration of the destruction process depends on geometrical and physical and mechanical properties of the object under investigation $[9,10]$. At this, relative coordinates of distinguished points in the rock massif and the model built on the basis of different physical methods practically coincide. It should be noted that duration of the destruction of the 
Equivalent material tests data

\begin{tabular}{|l|c|c|c|c|c|}
\hline \multirow{2}{*}{\multicolumn{1}{|c|}{ Name }} & \multicolumn{5}{|c|}{ Paraffin content in sand-paraffin mixture, \% } \\
\cline { 2 - 7 } & 1.6 & 1.8 & 2.0 & 2.2 & 2.4 \\
\hline Mean-square deviation & $2.2-9.1$ & $3.2-12.3$ & $3.0-7.7$ & $3.3-11.0$ & $9.0-13.5$ \\
\hline Uniformity factor of the massif & $4.4-18.2$ & $4.9-13.7$ & $0.8-8.0$ & $1.5-6.4$ & $0.6-7.0$ \\
\hline
\end{tabular}

model under investigation varies from fractions of a second to several months (years).

In simulating, when separate elements move down the inclined plane and other fast processes occur (the first group), the time scale is determined by the geometrical scale according to the formula

$$
M_{t}=\sqrt{M_{l}}
$$

where $M_{t}$ is the time scale; $M_{l}$ is the linear simulation scale.

In case of simulating pillar and exposure stability in the rock massif, along with the linear simulation scale the volume weight of rocks should be considered. The generalized experimental time scale in simulating is determined as follows

$$
M_{t}=M_{\gamma}^{2} \cdot M_{l}^{2.7}
$$

where $M_{\gamma}$ is the material volume weight scale.

Physical models of various forms of stopes typical for Kryvyi Rih iron ore basin were tested in laboratory conditions to verify the obtained empirical equations determining the qualitative composition of the equivalent material.

The input data for laboratory simulation were as follows: shapes of stopes - rectangular, diamond and domed; stope height $-75,80$ and $90 \mathrm{~m}$; stope length along the strike $-20,25,30,35,40 \mathrm{~m}$; stope width average thickness, $60 \mathrm{~m}$; dip $-60^{\circ}$; intervening pillar width - equal to stope width; temporary ultimate compressive resistance for ore, rocks of hanging and foot walls $-125,80$ and $110 \mathrm{MPa}$ respectively; unit load on a stope from overlying rock $-400 \mathrm{t} / \mathrm{m}^{2}$. Stope life time was determined according to intensity of mining and made 9,12 and 15 months.

A laboratory model was a box with front and back walls made of glass. In the box metal conductors (sensors) for detecting rock fracturing and uniformity loss were placed.

Experimental procedure. The box was filled with layers of the equivalent material with corresponding physical and mechanical properties of the ore and waste rocks. Then, the external load simulating weight of the overlying rocks was applied to the formed massif.

In the ore massif, stopes of $6125 \mathrm{~cm}^{3}$ and of the form under investigation were cut with pillars between them. In the model 3 stopes and 4 pillars were formed across the strike. Then the state of the stopes and pillars were monitored for a certain period of time considering its scale, and readings of resistance strain sensors in the model were taken. When the massif was destroyed, the amount of the destroyed material and the volume of the newly formed stope were determined (Fig. 4).
The strain sensor data expressed in terms of ultimate compressive resistance for stopes of various forms are given in Fig. 5.

As is seen in the diagram, the pillar compressive resistance decreases from 125 to 120 ...60 MPa depending on the stope shape. Thus, after exposures in rectangular, diamond and domed stopes within 9, 11 and 14 months respectively, compressive resistance of intervening pillars decreases and the formed stopes are destroyed.

Comparison of the data obtained through simulating applying the NDGRI methods enables the conclusion that the formed stopes remain stable during their design

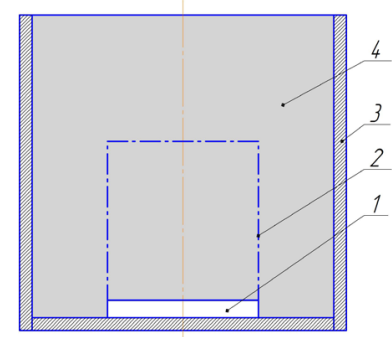

$a$

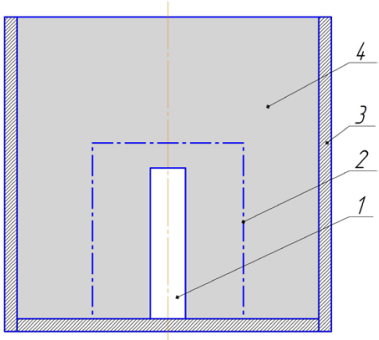

$c$

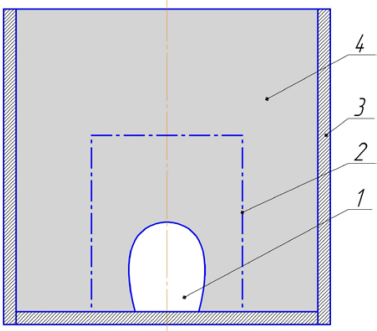

$e$

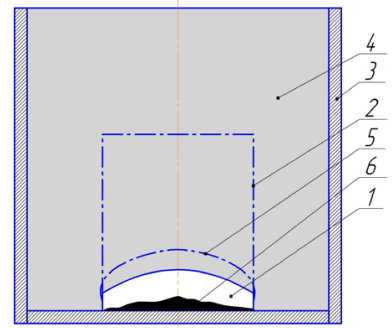

$b$

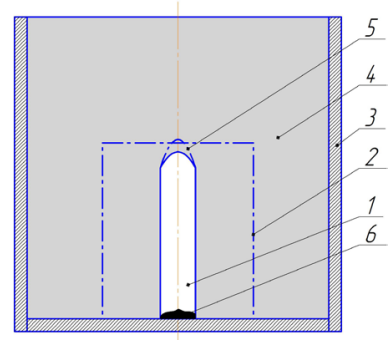

$d$

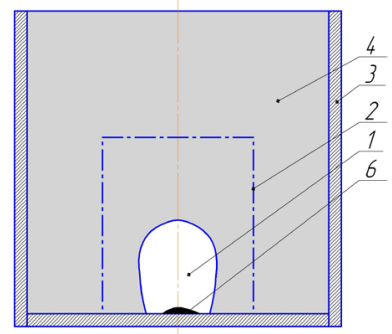

$f$
Fig. 4. Stages of simulating stability of compensating rooms of various forms:

$a, b, c, d, e, f$-stages of simulation; 1 - the compensating room; 2 - the boundary of a designed block; 3 - the model; 4 - the equivalent material; 5 - boundaries of zones of decreased and increased stresses; 6 - the destroyed equivalent material 


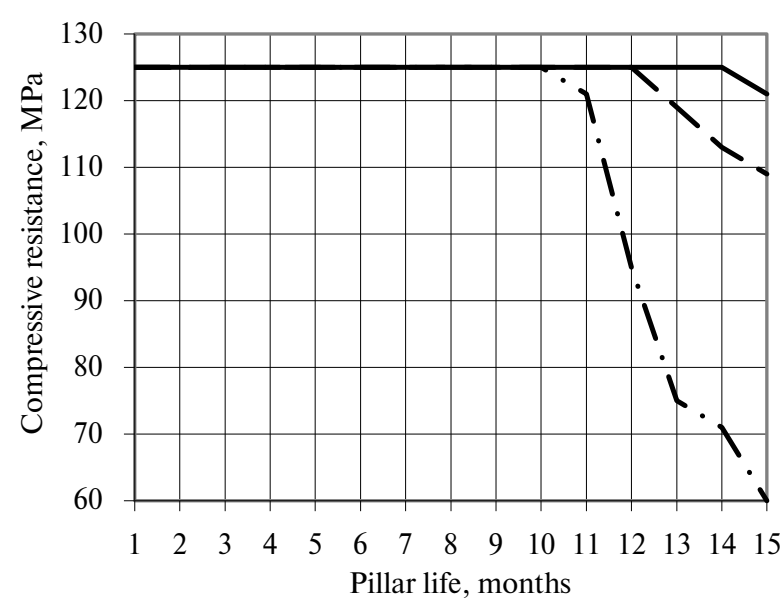

Fig. 5. Dependency of compressive resistance of a pillar on its life at the stope height of $90 \mathrm{~m}$ and length of $20 \mathrm{~m}$ :

1, 2, 3 -domed, diamond and rectangular stopes respectively

life. However, it should be noted that domed stopes with the dome in the upper part are the most stable.

Thus, the suggested empirical functions enable quick determination of the qualitative composition of the equivalent material, creation of the rock model that is capable of reflecting natural processes over time occurring at underground mining operations.

Conclusions and recommendations for further research. The laboratory tests have enabled empirical dependencies for determining the qualitative composition of the equivalent material. The quantitative composition of the equivalent material based on the sand-paraffin mixture (34\% of cast iron and granite chips, $66 \%$ of quartz sand, mica and paraffin) represents the investigated rocks of Kryvyi Rih iron ore basin with corresponding physical and mechanical properties in laboratory conditions.

\section{References.}

1. Khomenko, O., Sudakov, A., Malanchuk, Z. and Malanchuk, Ye., 2017. Principles of rock pressure energy usage during underground mining of deposits. Naukovyi Visnyk Natsionalnoho Hirnychoho Universytetu, 2, pp. 35-43.

2. Kazakov, V. L., Paran'ko, Y. S., Smetana, N. H., Shypunova, V.A., Kotsyuruba, V.V. and Kalynychenko, O.A., 2005. Natural geography of the Kryvbas. Kryvyi Rih: Vydavnychyi dim.

3. Andreev, B. M., Brovko, D. V. and Khvorost, V. V., 2015. Determination of reliability and justification of object parameters on the surface of mines taking into account change-over to the lighter enclosing structures. Metallurgical and mining industry, 12, pp. 378-382.

4. Mulyavko,V.I., Oleynik,T.A., Oleynik, M. O., Mikhno, S. V. and Lyashenko, V. I., 2014. Innovation technologies and machinery for separation of feebly magnetic ores. Obogashchenie Rud, 2(350), pp. 4349.
5. Fedko, M. B., Kolosov, V.A., Pismennyi, S. V. and Kalinichenko, Ye. V., 2014. Economic aspects of changeover to TNT-free explosives for the purposes of ore underground mining in Kryvyi Rih basin. Naukovyi Visnyk Natsionalnoho Hirnychoho Universytetu, 4, pp. 79-84.

6. Tarasyutin, V. M., 2015. Geotechnology features of high quality martite ore from deep mines of Kryvyi Rih basin. Naukovyi Visnyk Natsionalnoho Hirnychoho Universytetu, 1, pp. 54-60.

7. Khomenko, O. Ye. and Maltsev, D. V., 2013. Laboratory research of influence of face area dimensions on the state of uranium ore layers being broken. Naukovyi Visnyk Natsionalnoho Hirnychoho Universytetu, 2, pp. 31-37.

8. Bulat, A. F., Mineev, S. P., Bryukhanov, A. M. and Nikiforov, A.V., 2013. Development of classification procedure for gas-dynamic events in coal mines. Journal of Mining Science, 49, pp. 894-901.

9. Stupnik, N. I., Kalinichenko, V.A., Kolosov, V.A., Pismenniy, S. V. and Fedko, M. B., 2014. Testing complex-structural magnetite quartzite deposits chamber system design theme. Metallurgical and mining industry, 2, pp. 89-93.

10. Kononenko, M., Khomenko, O., Sudakov, A., Drobot, S. and Lkhagva, Ts., 2016. Numerical modelling of massif zonal structuring around underground working. Mining of Mineral Deposits, 12(3), pp. 101-106.

11. Stupnik, N., Kalinichenko, V., Kolosov, V., Pismennyy, S. and Shepel, A., 2014. Modeling of stopes in soft ores during ore mining theme. Metallurgical and mining industry, 3, pp. 32-36.

12. Rymarchuk, B. I., Shepel, O. L. and Khudyk, M. V., 2017. Expediency of application of the vertical concentrated charges to decrease losses of ore on a lying wall of deposits. Naukovyi Visnyk Natsionalnoho Hirnychoho Universytetu, 3 pp. 32-37.

13. Lapshin, A. A., 2014. Effect of a hardening tab in the cleaning chambers on the microclimate of deep mines. Eastern European Journal of Advanced Technology, 2/10(68), pp. 3-11.

14. Plevako, V., Potapov, V., Kycenko, V., Lebedynecj, I. and Pedorych, I., 2016. Analytical study of the bending of isotropic plates, inhomogeneous in thickness. Eastern-European Journal of Enterprise Technologies, 4(7(82)), pp. 10-16.

15. Kovalevska, I., Barabash, M. and Gusiev, O., 2016. Research into stress-strain state of reinforced marginal massif of extraction mine working by combined anchoring system. Mining of Mineral Deposits, 10(1), pp. 31-36.

\section{Визначення якісного складу еквівалентного матеріалу для фізико-механічних властивостей гірських порід Криворізького залізнорудного басейну}

\section{М.І. Ступнік, В. О. Калініченко, С. В. Письменний, О. В. Калініченко}

Державний вищий навчальний заклад „Криворізький національний університет“, м. Кривий Ріг, Україна, e-mail: prrkk@mail.ru 
Мета. Створити модель складу гірських порід Криворізького залізорудного басейну шляхом лабораторних досліджень еквівалентного матеріалу.

Методика. Використані методи математичного моделювання та експериментальних досліджень.

Результати. Встановлені умови подібності моделі, побудовані залежності фізико-механічних властивостей еквівалентного матеріалу від процентного співвідношення компонентів, що входять до нього. У результаті досліджень встановлено, що при моделюванні складу порід гірського масиву Криворізького залізорудного басейну в лабораторних умовах доцільно використовувати еквівалентний матеріал на основі піщано-парафінової суміші, що складається з: гранітної крихти, чавуну, кварцового піску, слюди й парафіну. Встановлено, що кількісний склад суміші еквівалентного матеріалу подібний до гірських порід Криворізького залізорудного басейну при наступному співвідношенні: $34 \%$ чавуну й гранітної крихти, $66 \%$ кварцового піску, слюди й парафіну. У peзультаті апроксимації залежностей отримані емпіричні рівняння коефіцієнта Пуассона й бічного розпору еквівалентного матеріалу, що безпосередньо залежать від процентного співвідношення чавуну, гранітної крихти й парафіну. Встановлено, що зі збільшенням процентного співвідношення парафіну в еквівалентному матеріалі, коефіцієнти Пуассона й бічного розпору збільшуються.

Наукова новизна. Уперше встановлені емпіричні залежності коефіцієнта Пуассона й межі міцності зразка від процентного співвідношення парафіну та чавуну. Коефіцієнт Пуассона й коефіцієнт бокового розпору в еквівалентному матеріалі на піщано-парафіновій основі залежать від кількісного співвідношення парафіну й чавуну та описуються експоненціальною й статечною функціями.

Практична значимість. Отримані результати лабораторних досліджень дозволяють створити з достатньою точністю модель породного складу гірського масиву, що дозволяє досліджувати у часі процеси, які протікають у гірських породах, при підземній розробці залізорудних родовищ.

Ключові слова: коефіцієнт Пуассона, еквівалентний матеріал, подоба, модель, масштаб, пішано-парафінова суміш, чавун, слюда

\section{Определение качественного состава эквивалентного материала для физико- механических свойств горных пород Криворожского железорудного бассейна}

\author{
Н. И. Ступник, В.А. Калиниченко, С. В. Письменный, \\ Е. В. Калиниченко
}

Государственное высшее учебное заведение „Криворожский национальный университет“, г. Кривой Рог, Украина, e-mail: prrkk@mail.ru

Цель. Создать модель состава горных пород Криворожского железорудного бассейна путем лабораторных исследований эквивалентного материала.

Методика. Использованы методы математического моделирования и экспериментальных исследований.

Результаты. Установлены условия подобия модели и натуры, построены зависимости физикомеханических свойств горных пород эквивалентного материала от процентного соотношения компонентов входящих в него. В результате исследований установлено, что при моделировании состава пород горного массива Криворожского железорудного бассейна в лабораторных условиях целесообразно использовать эквивалентный материал на основе песчано-парафиновой смеси, состоящей из: гранитной крошки, чугуна, кварцевого песка, слюды и парафина. Установлено, что количественный состав смеси эквивалентного материала подобен горным породам Криворожского железорудного бассейна при следующем соотношении: $34 \%$ чугуна и гранитной крошки, 66 \% кварцевого песка, слюды и парафина. В результате аппроксимации зависимостей получены эмпирические уравнения коэффициента Пуассона и бокового распора эквивалентного материала, которые напрямую зависят от процентного соотношения чугуна, гранитной крошки и парафина. Установлено, что с увеличением процентного соотношения парафина в эКвивалентном материале, коэффициенты Пуассона и бокового распора увеличиваются.

Научная новизна. Впервые установлены эмпирические зависимости коэффициента Пуассона и предела прочности материала от процентного соотношения парафина и чугуна. Коэффициент Пуассона и коэффициент бокового распора эквивалентного материала на песчано-парафиновой основе зависят от количественного соотношения парафина, чугуна и описываются степенной функцией.

Практическая значимость. Полученные результаты лабораторных исследований позволяют создать с достаточной точностью модель породного состава горного массива, которая позволяет исследовать во времени процессы, протекающие в горных породах, при подземной разработке железорудных месторождений.

Ключевые слова: коэффициент Пуассона, эквивалентный материал, подобие, модель, масштаб, песчано-парафиновая смесь, чугун, слюда

Рекомендовано до публікації докт. техн. наук Н. Ю. Швагером. Дата надходження рукопису 14.10.16. 